\title{
Impact of National Competitiveness on Economic Growth and Income Level - Evidence From the Selected Post-Soviet Countries
}

\author{
Aziz Sodikov $^{1}$, Zuhriddin Rizaev ${ }^{1,2}$, Lee Chin ${ }^{2} \&$ Shahnoza Ochilova ${ }^{1}$ \\ ${ }^{1}$ International Ratings and Indices Department, Ministry of Finance, Tashkent City, Uzbekistan \\ ${ }^{2}$ School of Business and Economics, Universiti Putra Malaysia, Serdang, Malaysia \\ Correspondence: Lee Chin, School of Business and Economics, Universiti Putra Malaysia, 43400 UPM, Serdang, \\ Selangor Darul Ehsan, Malaysia. Tel: 60-3-9769-7769. E-mail: leechin@upm.edu.my
}

Received: September 21, 2020

Accepted: October 25, 2020

Online Published: January 11, 2021

doi:10.5430/rwe.v12n2p17

URL: https://doi.org/10.5430/rwe.v12n2p17

\begin{abstract}
This paper investigates the impact of national competitiveness on productivity, economic growth and income per capita in the selected post-Soviet countries between 2004 and 2018. In this paper, 2019 edition of the Global Competitiveness Index (GCI), which is composed of 12 pillars such as namely institutions, infrastructure, ICT adoption, macroeconomic stability, health, skills, product market, labour market, financial system, market size, business dynamism and innovation capability, is used as a proxy for the national competitiveness and productivity for the empirical analysis purposes. The findings reveal that: (1) the GCI is highly correlated with productivity level and the selected post-Soviet countries with higher level of national competitiveness had higher long-term economic growth and income per capita, (2) Russia and Kazakhstan more benefited from rising per capita income associated with enhanced national competitiveness (or productivity growth) compared to other selected former Soviet states, (3) among the GCI factors, ICT adoption, macroeconomic stability, market size and healthy life expectancy were major levers of productivity growth that influenced the national competitiveness, positively and significantly contributing to an increase in the income level in the selected post-Soviet countries in 2004-2018 period.
\end{abstract}

Keywords: competitiveness, productivity, income, economic growth, post-Soviet countries

\section{Introduction}

National competitiveness is an important concept in economic literature. Notable scholars attempted to give a definition to the national competitiveness. To name but a few, Scott and Lodge (1985) considers the national competitiveness as a capability of a country to invent, produce and trade goods and services in international markets by generating incomes depending on its resources. For Buckley et al. (1998), the notion reflects an ability to set right targets that is to be effective, and to achieve them at the lowest possible cost. OECD (1992) saw it as the extent to which a country is able to produce goods and services satisfying the requirements of the international markets with prevailing fair market and free trade conditions and at the same time, to facilitate a sustainable and raising earnings of the individuals over the long-term. In addition, Berger (2008) discerns four main theoretical definitions of national competitiveness: an aptitude of a nation for trading (price-based and non-price-based competitiveness), generating income (productivity gains), adapting to external changes (innovation and flexibility) and attracting capital and labour resources (FDI).

But Krugman (1994) critics that the above mentioned explanations were "elusive". In accordance with his arguments, the economic theories of a market economy are built on the base of the competitive environment, where competition is reckoned as a key driver of economic activities. Unlike companies, national economies do not directly compete with each other and do not go into liquidation. Therefore, attempting to define the notion of competitiveness is meaningless. It is rather a "dangerous obsession" (Krugman, 1994).

Notwithstanding there are scholars advocate that the concept of competitiveness makes sense and its practical importance should not be underestimated (Porter, 1990; IMD, 2003; Schwab, 2018). Presumably, thereby instead of endeavouring to define the competitiveness, many researchers investigated its drivers and the economic factors by which it is affected (Nguyen, 2009).

A "diamond" model developed by Porter (1990) suggests that national competitiveness is a complex concept which 
can be explained by multiple economic factors. Porter (1990) derive four main determinants of national competitiveness from various theories and incorporate them in his concept. They are "factor conditions" (from classical and neo-classical economics), "demand conditions" (from Rostow growth and product cycle theories), "related and supporting companies" (from polarization theory and Marshall's industrial districts) and "firm strategy, structure and rivalry" from Schumpeter's theories (Kordalska and Olczyk, 2015, p. 3). The IMD's World Competitiveness Yearbook and World Economic Forum`s (WEF) Global Competitiveness Report are good examples for attempts to measure the national competitiveness that applied composite and complex indicators.

According to IMD (2003), the national competitiveness is "a field of economic knowledge, which analyses the facts and policies that shape the ability of a nation to create and maintain environment that sustains more value creation for its enterprises and more prosperity for its people". By contrast, putting forward slightly different view, Schwab (2018) determines it "as the set of institutions, policies and factors that determine a country's level of productivity". In 2004, combining Jeffrey Sachs's Growth Development Index (macroeconomic ranking) and Michael Porter's Business Competitiveness Index (microeconomics ranking), WEF introduced a new complex index, which is known as Global Competitiveness Index (GCI). The GCI is consisted of 12 pillars that are considered as factors of national competitiveness and are conceptualized on the basis of key economic theories such as endogenous growth theory, Keynesian economic theory, classical and neoclassical economic theories, new trade theory and development economics (Kordalska and Olczyk, 2015).

This study does not intend to revisit the theoretical debate mentioned above, instead, it addresses the conceptual framework of national competitiveness developed by Schwab (2018) to examine whether ameliorations in the national competitiveness maintained the long-term economic growth in the selected former Soviet states, including Armenia, Azerbaijan, Kazakhstan, Kyrgyz Republic, Moldova, Russia, Tajikistan and Ukraine, and Georgia. After the demise of the Soviet Union in 1991, the Central Asian states gained independence and started its transition toward a market economy. However, the transition process has been difficult and uneven. After 27 years, Russia and Kazakhstan had achieved medium-high income with Gross Domestic Product per capita of $\$ 11,289$ and $\$ 9,401$ in 2018; however there are some countries like Tajikistan $(\$ 827)$ and Kyrgyz Republic $(\$ 1,293)$ that their economic growth are lagging far behind. Therefore, it is interesting to explore what country-specific factors that are affecting these differences of economic growth. The present study proposed that the effect of the national competitiveness on income growth is mediated by the differences across countries. This is because every country is unique in terms of economic ideology, system, structure and attributes. Especially, in the era of globalisation when the national economies focus to specialize according their comparative advantages, the drivers of productivity may differ from one country to another. Therefore, this paper claims that improvements in country's performance in the GCI factors over time have different effects on the level of income per capita depending on the country-specific characteristics. Hence, this study intended to look at the individual effects of the factors of competitiveness (the GCI pillars score) on per capita income.

This paper makes two contributions to extant research. First, despite numerous studies on the impact of national competitiveness on income per capita, to our knowledge, there have been lack a of study attempts analyzing the national competitiveness in the post-Soviet countries. Second, this study used the latest 2019 edition of the Global Competitiveness Index (GCI 4.0 pillars score). The latest Global Competitiveness Index (GCI) composed of 12 pillars, namely institutions, infrastructure, ICT adoption, macroeconomic stability, health, skills, product market, labour market, financial system, market size, business dynamism and innovation capability. The published literature has not concurrently studied the roles of 12 pillars on the income per capita. This study attempted to explore this gap by estimating the country-specific effects of the GCI factors upon the per capita income over time and argues that these effects are mediated by the difference across countries.

This paper is organized as following: Section 2 provides a brief literature review on the national competitiveness and economic growth. Section 3 discusses the theoretical framework, methodology and data description. Section 4 covers the results and discussion. Finally, the conclusion is presented by summarizing the main findings of the paper along with the policy implications.

\section{Literature Review}

Since Adam Smith introduced concept of competition as the key driving force of markets, it has been one of the most focal topics in the economic research. If competition disregarded, market efficiency would not be implied, markets would not be strained for further improvements and innovations would not take place promptly (Berger, 2008). The microeconomic level competition, and also regarded as the firm level competitiveness, is applied on the firm scale. This concept is considered relatively compliant and straightforward: a more competitive a firm will get (can be 
measured in terms of market turnover, profitability, strategic management, customer satisfaction, etc.,), the greater market share will gain (Bristow, 2005; Kitson, Martin, \& Tyler, 2004). The firms with less competitive features, on the other hand, will face declining market shares and at some degree would eventually go bankrupt and exit the market (Hibbs, 1983). Nevertheless, there is no such pure segregated competitiveness theory, especially, in the macroeconomic context. When nations are treated as profit-seeking firms in the market, presuming that competition would take place in the same market for the identical goods and services. In point of fact, nations that sell goods and services in the global market not only compete with each other, moreover, with each other's main export markets and prime channels for essential imports (Krugman, 1994). In addition, the economic performance of some nations lags behind, in other words, uncompetitive. Unlike firms, nations do not go out of the business rather they remain at the bottom line of the competitive order (Kitson et al., 2004). The competitiveness could be referred to any kind of characteristics, whereby at the macroeconomic level, wide range of concepts are merged to form a framework for outlining the concept of national competitiveness (Alexoaei, 2020). In the macroeconomic context, higher degree of national competitiveness actually links with higher level of standard living: the concept does not limited only how well nations are performing at global markets, rather, it embraces on internal political, economic and societal structure that eventually attracts investment, human capital and innovations from abroad (Engel \& Siczek, 2018; Herman, 2018; Im \& Choi, 2018; Sölvell, 2015; Zhou, Zhou, \& Wang, 2015).

Porter (1990) stresses that the notion of national competitiveness is associated with the productivity of national economy, which is gauged by the output produced per unit of factors of production - capital, labour and natural resources. The more productive a country is, the more competitive its economy becomes. A rise in productivity boosts economic growth increasing employment and per capita real income that enables individuals to invest more in their healthcare, education and living conditions. Thus, improved human capital further stimulates productivity and contributes to long-term sustainable economic growth. In general, the level of productivity determines the living standards and overall prosperity of a nation in the future.

Some scholars (Porter, 2003; Kharlamova and Vertelieva, 2013; Rusu and Roman, 2018) argue that in order to be competitive, a country should be open for international competition as well. In particular, neo-classical and classical economists suppose the national competitiveness to be associated with an exporting power of a country (Petryle, 2016). Free market and fair-trade conditions allow capital, labour and technology to unreservedly flow across countries. As an economy, especially companies at all levels can utilize capital, labour and technology at the lowest possible cost as per their free choices, they tend to become more effective, efficient and thus, more competitive in the international arena. Fierce competition in the international markets for goods, services and financial resources encourages companies to be more innovative. A thirst for innovations, on the one hand, fosters them to cooperate with their domestic and foreign partners carrying out joint-projects and favouring knowledge-sharing among nations. On the other hand, it develops a head-hunting and stimulates competition in the labour market.

In fact, the competitive companies have much ability to increase countries` export potential. Export-oriented countries have a strong national currency, higher real wages (or income per capita) and living standards. Offering higher returns on capital with relatively lower risks, they are also more attractive for foreign direct investment (FDI). Increasing FDI inflow purports new job places for unemployed individuals, higher tax revenues for governments and further investments in infrastructure, healthcare and education. Therefore, the concept should be supplemented with the role of government consisted in developing country's capability to create a favourable environment for companies to be more competitive (Cornelius, 2002). To conclude, given that the productivity of the companies reflects overall productivity of an economy, the competitiveness at macro-level is determined by that of at micro-level (Porter et al, 2000; Porter, 2003). Moreover, sustainable long-term economic growth and national well-being can be considered as ultimate goals of the national competitiveness, whilst openness to international trade and FDI influx are factors influencing it.

There is plenty of economic literature examining the economic factors that affect the national competitiveness. The study of Mihaela (2016) showed that the quality of labour force is essential to achieve regional competitiveness. The result is supported by Guerrero et al. (2016) whose study showed that human capital had a stronger impact on regional competitiveness than economic factors like GDP per capita. However, the study of Reyes and Useche (2019) found otherwise. Analyzing the performance and the relationship between competitiveness, real gross domestic product (GDP) growth and human development in 20 countries of the Latin America and Caribbean region during the 2006-2015 period, Reyes and Useche (2019) found no statistically significant relationship between economic growth and human development.

As discussed earlier, there is not a unique perspective regarding the concept of competitiveness. The economic 
literature proposed the use of competitiveness indices for measuring the competitiveness. Most of the global competitiveness indices are used at national level. There are indices that are utilized at regional level: European Competitiveness Index, World Knowledge Competitiveness Index, the United Kingdom Competitiveness Index proposed by Robert Huggins Associates and the Atlas of Regional Competitiveness of Eurochambers (Mihaela, 2016). Most of them address the Global Competitiveness Index (GCI) as a proxy for the level of competitiveness. For instance, analyzing the economies of the Central and Eastern European (C.E.E.) countries, including Bulgaria, Czech Republic, Estonia, Hungary, Lithuania, Latvia, Poland, Romania, Slovenia and Slovakia and clustering them as per their stage of economic development, Rusu and Roman (2018) found that GDP, inflation rate, trade, labour productivity and costs of business start-up procedure are main determinants of the national competitiveness for efficiency-driven economies, whereas GDP, inflation rate, tax rate, FDI, trade and costs of business start-up procedure are for innovation-driven economies. In regard to the C.E.E. transition economies, the factors affecting the national competitiveness are limited with GDP, inflation rate and labour productivity. These findings suggest that despite certain similarities, the factors above appreciably vary between economies.

The findings of Dadgar et al. (2018) confirm the existence of a strong positive relationship between the GCI score (the national competitiveness level) () and economic growth. But the authors infer that it is relatively stronger in upper middle-income countries compared to high income countries. Kharlamova and Vertelieva (2013) claims that an openness of a country to international trade is the most important factor effecting its national competitiveness level. Besides, the study also asserts that countries with higher GCI ranking (i.e. higher level of national competitiveness) tend to have more sustainable economic growth and higher living standards.

However, Kordalska and Olczyk (2015) skeptically treats the issue of whether there is a bidirectional or unidirectional causality between the GCI and the economic growth and considers it as a still open question in the literature. In fact, a panel Granger causality analysis of the study reveals that the relationship between these economic indicators is rather unidirectional. In other words, the GDP growth of the countries has real impact upon the national competitiveness. The converse effect is confirmed in case of only 4 countries (China, India, Russia and US) out of 114. Following Kordalska and Olczyk (2015), Petryle (2016) argues that the GCI score of a country is uncorrelated (weak correlation) with its GDP growth rate, yet it is negatively correlated with the standard deviation of the GDP growth.

In General, most of the previous studies agreed that the national competitiveness is positively associated with productivity and income growth. However, there is a few literature that attempted to examine the impact of the GCI factors on per capita income. In addition, the available published works failed to consider the country-specific effects of the national competitiveness upon the level of income per capita. Since every country is unique, the productivity drivers may differ from one country to another. Therefore, this study has found the need to address the drawbacks by conducting a thorough investigation on the impact of the GCI factors, in particular the effects of individual 12 pillars on per capita income.

\section{Methodology}

\subsection{Theoretical Framework}

In 2018, WEF introduced a new modified version of the GCI which is known as the GCI 4.0 (Appendix of 4.0 refers to the Fourth Industrial Revolution (4IR)). In contrast to its predecessors, this concept provides a range of insights about newly arising determinants of national productivity and behavior of national economies towards new global challenges issued by the 4IR. For example, previous editions of the index reckoned that the pathway to development for lower-income economies is "through progressive industrialization by leveraging low-skilled labour" and they hereby distinguish economies as per their stage of development (factor-driven, efficiency-driven and innovation-driven economies) weighting pillars respectively (Schwab, 2018).

However, the GCI 4.0 suggests a "level playing field" for each economy to pursue its own strategy that takes national interests into account (Schwab, 2018, p. 9). In this context, human capital, innovation, resilience and agility should be regarded as "defining features" of national competitiveness (Schwab, 2018, p. 7). It is not zero-sum game and economies can be competitive simultaneously. The main idea behind this concept is that since ICTs and technological advancement substantially accelerated the industrialization in the era of 4IR, a great opportunity is afforded for low-income countries to demonstrate rapid economic upturns and faster undergo the development pathway that once has been passed by the developed countries. However, the index emphasizes the cruciality of adhering holistic approach by countries to achieve higher level of competitiveness.

Both, 2018 and 2019 editions of the index are identical in terms of theoretical background, though 2019 version (the 
GCI 4.0) is up-to-dated and enriched with couple of new indicators. Hence, in this paper, the GCI 2019 pillars are used as factors that defining the national competitiveness and productivity level for the purpose of empirical analysis. The index is composed of 12 pillars, namely institutions, infrastructure, ICT adoption, macroeconomic stability, health, skills, product market, labour market, financial system, market size, business dynamism and innovation capability, that are deemed as key productivity enhancers pursuant to Schwab`s (2018) conceptualization (Figure 1).

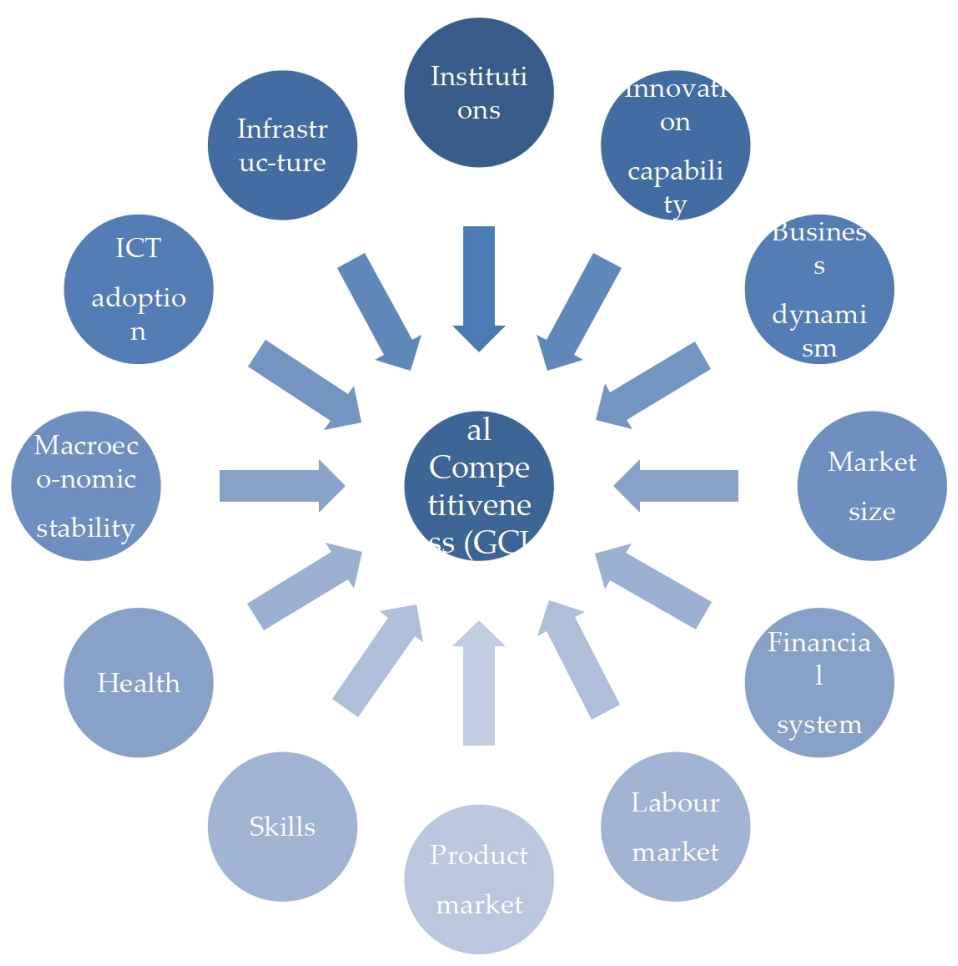

Figure 1. Factors effecting the national competitiveness according to the GCI 4.0 methodology

There are 103 indicators, out of which 56 are based on statistics (hard data) and contribute $70 \%$ of the total GCI 4.0 score, whereas the rest $30 \%$ of weight belongs to 47 indicators that are derived from WEF's Executive Opinion Survey (soft data). Nevertheless, the weight of soft data indicators was significantly high (more than two-thirds of the overall score) in previous versions of the index. Therefore, the critics blamed the GCI indicators for being insufficiently grounded by theories, methodological weaknesses and large proportion of subjective indicators (Berger and Bristow, 2009 and Carvalho et al., 2012).

In general, Schwab (2018) defines competitiveness "as the set of institutions, policies and factors that determine a country's level of productivity". Based on this concept, the study advanced its two main arguments. The first argument is that improved national competitiveness leads to higher level of productivity and economic growth in the long run. Indeed, if the GCI is a good gauge of competitiveness, there should be a strong positive correlation between the GCI and productivity level of a country. Meanwhile, the second argument states that improvements in the national competitiveness over time leads to higher per capita income. Schwab (2018) put forward these arguments on the base of general conclusions drawn by analyzing a cross-sectional data that comprises the economic indicators of 140 countries.

Unlike Schwab (2018), the following paper aims to test the arguments above and examine whether they are hold in smaller sample, in particular in case of the selected post-Soviet states. It scrutinizes whether a productivity growth and an increase in income per capita is associated with higher level of the national competitiveness in these economies between 2004 and 2018. In addition, looking at individual and country-specific effects of the competitiveness factors, this study also analyses the levers of productivity growth that influenced the national competitiveness and made per capita income to increment in the selected post-Soviet countries from 2004 to 2018. It is important to note that there are few literature that examined the impact of the GCI factors on per capita income in 
the post-Soviet countries. Thus, it contributes to debates about national competitiveness that was discussed in the previous section. Hence, the hypotheses put forward by this paper are as following:

Hypothesis 1: Did the selected post-Soviet countries with higher level of national competitiveness achieve a higher long-term economic growth?

Hypothesis 2: Did enhancement of national competitiveness of the selected post-Soviet countries increase per capita income between 2004 and 2018? If yes, what factors did play the defining role in this?

Given that the following study proposes to test the arguments offered by Schwab (2018) in case of the former Soviet countries, the designed hypotheses above complement each other. Proving the first hypothesis is necessary to test the second hypothesis and makes its results meaningful and worthwhile. More precisely, if the GCI estimate is a good proxy for the national competitiveness and productivity level and it is positively correlated with long-term growth, the improvements in the national competitiveness over time will lead to higher per capita income.

To test the first hypothesis, this study follows Schwab`s (2018) approach which initially addressed to economic growth models developed by Solow (1957) and Hall and Jones (1999), but could not apply them due to data limitations. Instead, it used conditional convergence regression suggested by Mankiw et al. (1992) and Barro and Sala-i-Martin $(1992,2004)$. According to these researches, majority of neo-classical growth theories, in particular Solow-Swan or Ramsey-Cass-Koopmans theories of growth assume that both, the level of income and its growth rate are determined by the level of productivity.

As a theoretical background, Schwab (2018) applied the Solow-Swan growth theory model (equation 1), which suggests that the growth of capital stock per person $(k)$ is a function of the saving rate $(s)$, GDP per capita $(y)$, population growth $(n)$ and capital depreciation $(\delta)$ :

$$
k_{i t}=s_{i} f\left(A_{i t} k_{i t}\right)-\left(n_{i}+\delta_{i}\right)
$$

where:

$A_{i t}=$ total factor productivity for country $i$ at time $t$.

Applying a log-linear transformation and Taylor approximation to equation 1, Schwab (2018) found that economic growth is a negative function of the initial level of income per capital, but is a positive function of its steady-state level. This is a conditional convergence regression, which can be expressed as following:

$$
\gamma_{i t, t+T}=\beta_{0}-\beta_{1} \ln \left(y_{i t}\right)+\beta_{2} \ln \left(y_{i *}\right)+\epsilon_{i t}
$$

where:

$\gamma_{i t, t+T}=$ an average annual growth rate of GDP per capita for country $i$ between times $t$ and $t+T$;

$y_{i t}=$ GDP per capita for country $i$ at time $t$;

$y_{i *}=$ a steady-state level of GDP per capita for country $i$;

$\epsilon_{i t}=$ an error term.

However, finding an appropriate proxy for the steady-state level of income per capita $\left(y_{i *}\right)$ is perplexing task. To tackle this issue, Schwab`s (2018) applied the Solow-Swan growth model with a Cobb-Douglas production function and found that the steady state capital stock is $k_{i}^{*}=\left[s_{i} \frac{A_{i}}{\delta+n_{i}}\right]^{\frac{1}{1-\alpha}}$ According to this growth model, given constant rates of savings $(s)$, population growth $(n)$ and depreciation $(\delta)$, the growth rate depends on $A$.

Thus, the steady state level of GDP per capita is $y_{i}^{*}=A_{i}^{\frac{1}{1-\alpha}}\left[\frac{s_{i}}{\delta+n_{i}}\right]^{\frac{\alpha}{1-\alpha}}$. Once the logs are taken from both sides, the equation is as following:

$$
\ln \left(y_{i}^{*}\right)=\frac{1}{1-\alpha} \ln \left(A_{i}\right)+\frac{\alpha}{1-\alpha} \ln \left(\frac{s_{i}}{\delta+n_{i}}\right)
$$

Finally, by putting the equation 3 in 2 , the study obtained:

$$
\gamma_{i t, t+T}=\beta_{0}-\beta_{1} \ln \left(y_{i t}\right)+\tilde{\beta}_{2} \ln \left(A_{i}\right)+\tilde{\beta}_{2} \frac{\alpha}{1-\alpha} \ln \left(\frac{s_{i}}{\delta+n_{i}}\right)+\epsilon_{i t}
$$

where: $\widetilde{\beta}=\beta_{2} \times \frac{1}{1-\alpha}$ 
Here, it claims that since the consumption literature reveals no correlation between savings rate and income level and a weak negative correlation between population growth rate and income level, assuming $\beta_{2} \frac{\alpha}{1-\alpha} \ln \left(\frac{s_{i}}{\delta+n_{i}}\right)$ as a part of error term, that is $w_{i t}=\beta_{2} \frac{\alpha}{1-\alpha} \ln \left(\frac{s_{i}}{\delta+n_{i}}\right)+\epsilon_{i t}$, should not bias $\beta_{1}$ and $\widetilde{\beta}_{2}$ estimates:

$$
\gamma_{i t, t+T}=\beta_{0}-\beta_{1} \ln \left(y_{i t}\right)+\tilde{\beta}_{2} \ln \left(A_{i}\right)+w_{i t}
$$

Equation 5 shows that the growth rate of GDP per capita between time $t$ and time $t+T$ is negatively related to the initial level of GDP per capita, whilst positively to the level of productivity.

As Schwab (2018) asserts the GCI estimate for country $i$ is a good proxy for the level of productivity, $A_{i}$ is substituted by the GCI in equation 5 .

$$
\gamma_{i t, t+T}=\beta_{0}-\beta_{1} \ln \left(y_{i t}\right)+\tilde{\beta}_{2} \ln \left(G C I_{i}\right)+w_{i t}
$$

or

$$
\frac{\Delta \log (G D P p c)_{i, 2000-2018}}{18}=\beta_{0}-\beta_{1} \operatorname{logGDPpc} c_{i, 2000}+\tilde{\beta}_{2} \log G C I_{i, 2019}+\mu_{i}
$$

where:

$\frac{\Delta \log (G D P p c)_{i, 2000-2018}}{18}=$ annual average growth rate in each country $i$ (calculated as a difference in log GDP per capita (PPP terms) between 2000 and 2018;

$\log G C I_{i, 2019}=\log$ of the GCI score for the year 2019, which is the average of the scores of its 12 pillars;

$\log G D P p c_{i, 2000}=$ GDP per capita in PPP terms in 2000 .

Hence, the final regression equation dedicated to test the first hypothesis is obtained. If the GCI is a good proxy for the level of productivity, the regression analysis should generate a negative estimate of $\beta_{1}$ and a positive estimate of $\widetilde{\beta}_{2}$.

Schwab (2018) argues that the GCI 2019 embraces 12 factors (pillars of the index) that are considered as drivers of productivity and thereby, countries that optimize their performance on them tend to have not only higher long-term economic growth, but also higher level of income. The argument is solid as it is empirically proved by the study with cross-country evidence.

However, there is a few academic literature that attempted to investigate the impact of the GCI factors upon the level of income per capita, estimating country-specific effects. Every country is unique in terms of economic ideology, system, structure and attributes. Especially, in the era of globalisation when the national economies focus on specialization according to their comparative advantages, the drivers of productivity differ from one country to another.

Therefore, this paper claims that improvements in country`s performance in the GCI factors over time have different effects on the level of income per capita depending on the country-specific characteristics. To test the second hypothesis, it applies the following regression model:

$$
\ln \left(\gamma_{i t}\right)=\alpha_{0}+\sum_{j=1}^{k} \alpha_{j} \ln \left(x_{j i t}\right)+\beta_{i} D_{i}+\epsilon_{i t}
$$

where:

$\ln \left(\gamma_{i t}\right)=\log$ of GDP per capita (PPP terms) for country $i$ at time $t$ (dependent variable);

$\ln \left(x_{j i t}\right)=\log$ of the scores of the GCI 4.0 factor $j$ for country $i$ at time $t$ (independent variables);

$D_{i}=$ dummy variable for country $i$;

$\epsilon_{i t}=$ error term.

3.2 Data

In this paper, for the purpose of empirical analysis of the first hypothesis (equation 7), a cross-sectional data with 9 observations (Armenia, Azerbaijan, Kazakhstan, Kyrgyz Republic, Moldova, Russia, Tajikistan, Ukraine, and 
Georgia) is used. It covers the period from 2000 to 2018. The dependent variable is an annual average GDP growth rate in each country that is calculated as a difference in log of GDP per capita between 2000 and 2018. According to the dataset, mean and standard deviation of the annual average GDP growth rate of 9 countries between 2000 and 2018 is 0.046 and 0.014 , respectively. The first independent variable is the GCI 2019 score, which is the average of the scores of its 12 pillars ranging from 0 to 100. The mean of the GCI 2019 score of 9 countries is 59.37 and individual country scores do not much deviate from this mean with a standard deviation of 4.65. The highest GCI 2019 score is registered in Russia (66.7), whereas the lowest score is in Tajikistan (52.4). However, the difference between these economies in terms of the GDP per capita in 2000 is significant, registering 14,759.2 and 1,252.5 US dollars, respectively.

Table 1. Descriptive statistics

\begin{tabular}{lrrrrr}
\hline Variable & Obs & \multicolumn{1}{c}{ Mean } & \multicolumn{1}{c}{ Std. Dev. } & \multicolumn{1}{c}{ Min } & \multicolumn{1}{l}{ Max } \\
\hline Period & 105 & & & 2004 & 2018 \\
Country & 7 & & & & \\
GDP per capita (PPP terms, in US dollars) & 105 & $13,759.17$ & $6,418.21$ & $5,726.84$ & $26,669.22$ \\
Global Competitiveness Index (GCI) score & 104 & 52.93 & 5.04 & 43.33 & 66.70 \\
Pillar1 (Institutions) score & 83 & 45.93 & 7.69 & 33.33 & 61.00 \\
Pillar2 (Infrastructure) score & 83 & 51.98 & 10.77 & 23.33 & 77.40 \\
Pillar3 (ICT adoption) score & 83 & 48.54 & 10.18 & 26.67 & 77.00 \\
Pillar4 (Macroeconomic stability) score & 83 & 65.19 & 13.31 & 35.00 & 90.00 \\
Pillar5 (Health) score & 83 & 75.20 & 5.12 & 61.67 & 85.00 \\
Pillar6 (Skills) score & 83 & 56.29 & 8.20 & 40.00 & 69.90 \\
Pillar7 (Product market) score & 83 & 52.73 & 5.24 & 41.67 & 64.30 \\
Pillar8 (Labour market) score & 83 & 59.82 & 4.84 & 48.33 & 69.40 \\
Pillar9 (Financial system) score & 83 & 45.08 & 5.83 & 33.33 & 60.20 \\
Pillar10 (Market size) score & 83 & 47.42 & 18.44 & 23.33 & 84.20 \\
Pillar11 (Business dynamism) score & 83 & 46.75 & 8.31 & 35.00 & 71.50 \\
Pillar12 (Innovation capability) score & 83 & 34.27 & 6.27 & 23.33 & 52.90 \\
\hline
\end{tabular}

To test the second hypothesis, a strongly balanced panel data with 104 observations for a period of 2004-2018 is applied (Table 1). Notwithstanding, when the country-specific effects of each factor of the national competitiveness is estimated, the number of observations dwindled to 83 and it is associated with the methodological changes in the GCI index in 2007. Due to lack of data, the dummy variables of Kyrgyz Republic and Tajikistan are omitted and therefore, the number of countries decreased from 9 to 7 in this part of the analysis. Furthermore, as Moldova was excluded from the GCI 2009 Report, the number of observations for overall GCI score declined from 105 to 104.

There are at least three points to highlight. Firstly, since there is one-year time lag between the release of the GCI report and statistical data of its indicators, the values of the independent variables (the score of the GCI pillars) at time $t$ are regressed against the values of the dependent variable at time $t-1$. Secondly, the scores of all GCI versions before 2018 were in the range between 1 and 7. For that reason, the values of the overall index score and its pillars are re-scaled from 0 to 100 applying min-max transformation suggested by Schwab (2018, p. 642).

$$
\text { score }_{i, c}=\left(\frac{\text { value }_{i, c}-w p_{i}}{\text { frontier }_{i}-w p_{i}}\right) \times 100
$$

where:

value $_{i, c}=$ the raw value of country c for indicator $\mathrm{i}$; 
$w p_{i}=$ (worst performance) the lowest acceptable value for indicator $\mathrm{i}$;

frontier $_{i}=$ the best possible outcome for indicator $\mathrm{i}$.

Thirdly, the difference in time period selected for Hypothesis 1 and 2 is associated with availability of the GCI data. In fact, though the first GCI report was released in 2004, its Growth Competitiveness Index and Business Competitiveness Index were integrated into single index titled Global Competitiveness Index in 2005. And the last GCI report was published in 2019. As the GCI reports cover the statistical data with one-year time lag, 2004-2018 time period with 104 observations (Table 1) is selected to test the Hypothesis 2. By contrast, according to the equation (7), the time period for Hypothesis 1 is required to be long term. Given that the latest available GCI data is the GCI report 2019, which contains economic data for 2018, the GCI 2019 score is used as a proxy for the level of productivity and GDP per capita (PPP terms) in 2000 is as an initial level of income.

\section{Results}

\subsection{Hypothesis 1}

The results of the regression equation (7) that aims to test the first hypothesis are given in Table 2. According to the table, the estimated coefficients on the log of initial level of GDP per capita $\left(\beta_{1}\right)$ and the log of the GCI score $\left(\beta_{2}\right)$ are -0.028 (standard error -0.009 ) and 0.253 (standard error -0.08 ), respectively, and both are statistically significant at the level of 0.05 . Since the adjusted R-squared is 0.522 and the overall F-test is statistically significant, one can conclude that this OLS regression model fits well to the dataset. However, it is also important to note that relatively lower values of F-test and R-squared/Adjusted R-squared are possibly associated with a limited number of observations. In addition, the cross-country data is tested for an absence of heteroskedasticity problem applying Breusch-Pagan/Cook-Weisberg test. The $\chi^{2}$ statistics indicates that we fail to reject the null hypothesis of heteroskedasticity. Hence, the data is homoskedastic.

To sum up, $\beta_{1}$ is found to be negative, whilst $\beta_{2}$ to be positive. These empirical results corroborate the first hypothesis, suggesting that the GCI scores of the selected post-Soviet countries is highly and positively correlated with their productivity level. In other words, the improvements in the national competitiveness stimulated the productivity growth in the selected post-Soviet countries and thus led to higher long-term economic growth between 2000 and 2018.Hence, the finding of the following paper proves that Schwab`s (2018) argument (i.e. improved competitiveness leads to higher level of productivity and economic growth in the long-term) is valid even in small sample. Inasmuch as, in our sample of the selected post-Soviet states, the GCI estimate is found to good measure for national competitiveness and productivity level bringing about higher economic growth in the long run, one can look at how improvements in performance of these states in the GCI and its factors effected their income level from 2004 to 2018 .

Table 2. The results of the regression equation (7)

\begin{tabular}{lc}
\hline \multicolumn{1}{c}{ Variables } & Annual average GDP growth between 2000 and 2018 \\
\hline Log of GDP per capita (2000) & $-0.028^{* *}$ \\
& $(0.009)$ \\
Log of GCI 4.0 (2019) & $0.253^{* *}$ \\
& $(0.080)$ \\
Intercept & $-0.749^{* *}$ \\
Number of observations & $(0.267)$ \\
R-squared & 9 \\
Adjusted R-squared & 0.641 \\
F-test (model) & 0.522 \\
Breusch-Pagan/Cook-Weisberg test & $5.36^{* *}$ \\
\hline
\end{tabular}

Note: ${ }^{*} \mathrm{p}<0.1 ; * * \mathrm{p}<0.05 ; * * \mathrm{p}<0.01$ 


\subsection{Hypothesis 2}

There are two main techniques to analyze the panel data: fixed-effects model and random-effects model. In this paper, the regression equation (8) is estimated by using both techniques at the initial stage. Then, Hausman test is applied in order to choose the most appropriate one. Table 3 reports the estimation results of the fixed-effects and random-effects models.

\subsubsection{Fixed-Effects Model Estimations}

In the fixed-effects model, the coefficients on 4 out of 12 independent variables are found to be statistically significant at $95 \%$ and $99 \%$ confidence levels. All of these coefficients have a positive sign which conforms to the underlying theory. F-test for overall significance and F-test for significance of dummy parameters achieve a significance level of $99 \%$ too, implying the well fitness of the model to the data.

Table 3. Results of the regression equation (8)

\begin{tabular}{|c|c|c|}
\hline & Fixed-effects model & Random-effects model \\
\hline \multirow{2}{*}{ Log of Pillar1 score (Institutions) } & -0.009 & $1.357 * * *$ \\
\hline & $(0.145)$ & $(0.479)$ \\
\hline \multirow{2}{*}{ Log of Pillar2 score (Infrastructure) } & -0.057 & -0.270 \\
\hline & $(0.079)$ & $(0.240)$ \\
\hline \multirow{2}{*}{ Log of Pillar3 score (ICT adoption) } & $0.279 * * *$ & 0.393 \\
\hline & $(0.084)$ & $(0.254)$ \\
\hline \multirow{2}{*}{ Log of Pillar4 score (Macroeconomic stability) } & $0.192 * * *$ & $0.816^{* * *}$ \\
\hline & $(0.054)$ & $(0.181)$ \\
\hline \multirow{2}{*}{ Log of Pillar5 score (Health) } & $0.365 * * *$ & 0.410 \\
\hline & $(0.130)$ & $(0.493)$ \\
\hline \multirow{2}{*}{ Log of Pillar6 score (Skills) } & -0.207 & 0.090 \\
\hline & $(0.154)$ & $(0.483)$ \\
\hline \multirow{2}{*}{ Log of Pillar7 score (Product market) } & 0.058 & -0.244 \\
\hline & $(0.159)$ & $(0.574)$ \\
\hline \multirow{2}{*}{ Log of Pillar8 score (Labour market) } & -0.161 & 0.306 \\
\hline & $(0.175)$ & $(0.559)$ \\
\hline \multirow{2}{*}{ Log of Pillar9 score (Financial system) } & -0.046 & -0.461 \\
\hline & $(0.108)$ & $(0.348)$ \\
\hline \multirow{2}{*}{ Log of Pillar10 score (Market size) } & $0.256^{* *}$ & $0.858 * * *$ \\
\hline & $(0.122)$ & $(0.163)$ \\
\hline \multirow{2}{*}{ Log of Pillar11 score (Business dynamism) } & 0.175 & $-0.909^{*}$ \\
\hline & $(0.154)$ & $(0.469)$ \\
\hline \multirow{2}{*}{ Log of Pillar12 score (Innovation capability) } & -0.043 & $-0.452^{*}$ \\
\hline & $(0.104)$ & $(0.233)$ \\
\hline \multirow{2}{*}{ Intercept } & $6.257 * * *$ & 1.640 \\
\hline & $(0.872)$ & $(3.055)$ \\
\hline Number of observations & 83 & 83 \\
\hline Overall R-squared & 0.559 & 0.794 \\
\hline Between R-squared & 0.685 & 0.903 \\
\hline Within R-squared & 0.800 & 0.486 \\
\hline F-test (model) & $21.39 * * *$ & \\
\hline
\end{tabular}




\begin{tabular}{lcc}
\hline$\chi^{2}$-test (model) & & $270.3^{* * *}$ \\
Hausman test & $179.82^{* * *}$ & $177.10^{* * *}$ \\
F-test (fixed effect) & 0.347 & \\
$\sigma_{\mathrm{u}}($ sigm_u) & 0.051 & 0 \\
$\sigma_{\mathrm{e}}\left(\right.$ sigm_e $\left._{-}\right)$ & 0.979 & 0.051 \\
$\theta$ (rho) & & 0 \\
Pesaran CD test & & 1.504 \\
Modified Wald Test & & 4.90 \\
\hline
\end{tabular}

Note: ${ }^{*} \mathrm{p}<0.1 ; * * \mathrm{p}<0.05 ; * * * \mathrm{p}<0.01$.

\subsubsection{Random-Effects Model Estimations}

In the random-effects model, 5 out of 12 independent variables ' parameters are statistically significant at $90 \%$ and $99 \%$ confidence levels. Among them, log of business dynamism (Pillar11 score) and log of innovation capability (Pillar12 score) are negatively related to log of GDP per capita and in turn, this contradicts the GCI theoretical framework. The result of the $\chi^{2}$-test, which inspects whether all the coefficients in the model are different than zero, indicates the random-effects model also fits well to the data.

\subsubsection{Least Squares Dummy Variable Model (LSDV) Estimations}

Nonetheless, the Hausman test returns 177.1, which is statistically significant indicates that the null hypothesis of random-effects is preferred model, is rejected and it is concluded that the fixed-effects model better fits the data.

In the next stage, the estimates of fixed-effects model are checked for the absence of serial correlation and heteroskedasticity problems. To begin with, Pesaran CD (cross-sectional dependence) test is run to test whether cross-sectional dependence is present. If the residuals are correlated across entities (also called as "contemporaneous correlation"), the results are biased (Hoechle, no date). Here, the null hypothesis is that there is no cross-sectional dependence (no serial correlation). According to the Pesaran CD test results, it failed to reject the null hypothesis. Hence, the test suggests that residuals are not correlated across entities and thereby, there is no serial correlation. Then, Modified Wald Test is run and the obtained results failed to reject the null hypothesis (homoskedasticity). Hence, the result revealed that there is no heteroskedasticity problem.

As this paper more focuses on estimating the country-specific effects of the GCI factors upon the per capita income over time and argues that these effects are mediated by the difference across countries, the fixed-effects with least squares dummy variable model (LSDV) is applied for further empirical analysis. Besides, LSDV enables to estimate the pure effects of the GCI factors on income level by controlling for the unobserved heterogeneity.

Table 4 illustrates the results obtained through LSDV model. According to the table, the estimated coefficient on the $\log$ of GCI is 1.776 with standard error of 0.199 (Column 14). Both, t-test and F-test achieve a significance level of $99 \%$, while R-squared (0.926) and adjusted R-squared (0.92) confirm the goodness of fit of the chosen explanatory variable as it explains more than $90 \%$ of variations in the dependent variable. In short, the second hypothesis of this study is proved in case of 4 out 7 countries under review. More precisely, the relationship between the country`s GCI score and the level of per capita income is confirmed only in case of Armenia, Kazakhstan, Russia and Ukraine. In fact, a percentage increase in the overall GCI score (i.e. national competitiveness) rose per capita income on average by 1.776 percent in Armenia, by 2.346 percent in Kazakhstan, by 2.462 percent in Russia and by 1.509 percent in Ukraine between 2004 and 2018. These estimation results suggest that Russia and Kazakhstan benefited from rising per capita income associated with enhanced national competitiveness (or productivity growth) more than Armenia, Ukraine, Azerbaijan, Georgia and Moldova.

This finding can be additionally proved by the fact that both, Russia (43rd, \$26,669.22) and Kazakhstan (62.9th, $\$ 25,549.97$ ) possess higher GCI ranking and per capita income compared to their peers in the CIS region. Weak performance of the Ukraine is predominantly associated with adverse economic consequences of the political instability accompanied by "Orange revolution" in 2004 and "Euromaidan" in 2014 (BBC, 2014). Furthermore, the graphical demonstration (Figure 2) of this relationship also bears evidence that countries with higher level of national competitiveness tend to have higher level of per capita income in the long run. 


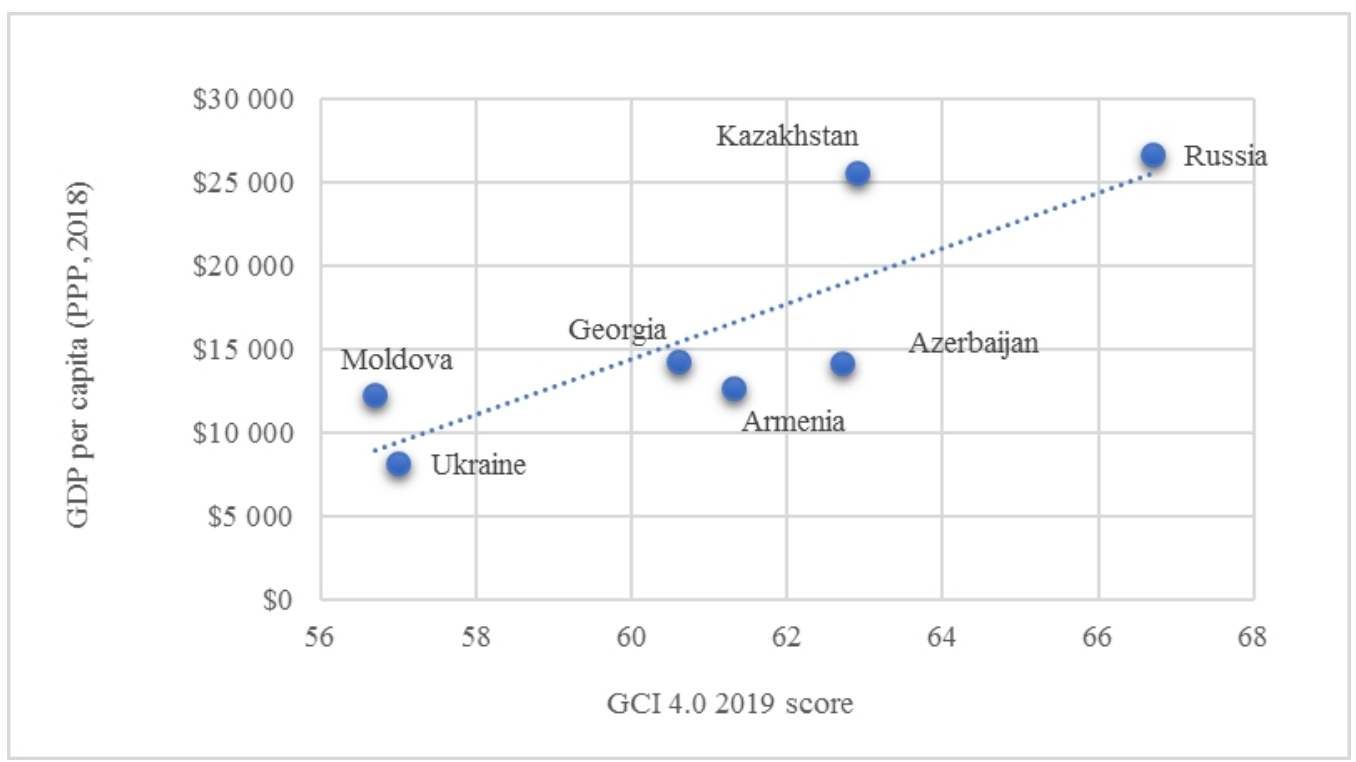

Figure 2. Competitiveness and income

Table 4. The results of the regression analysis using LSDV model

\begin{tabular}{|c|c|c|c|c|c|c|c|}
\hline & (1) & (2) & (3) & (4) & (5) & (6) & (7) \\
\hline Variable & \multicolumn{7}{|c|}{ Log of GDP per capita } \\
\hline \multicolumn{8}{|l|}{ Log of GCI score } \\
\hline Log of Pillar1 score (Institutions) & $\begin{array}{c}0.485 * * * \\
(0.099)\end{array}$ & & & & & & \\
\hline Log of Pillar2 score (Infrastructure) & & $\begin{array}{c}0.344 * * * \\
(0.052)\end{array}$ & & & & & \\
\hline Log of Pillar3 score (ICT adoption) & & & $\begin{array}{c}0.415^{* * *} \\
(0.039)\end{array}$ & & & & \\
\hline $\begin{array}{l}\text { Log of Pillar4 score (Macroeconomic } \\
\text { stability) }\end{array}$ & & & & $\begin{array}{c}0.362 * * * \\
(0.069)\end{array}$ & & & \\
\hline Log of Pillar5 score (Health) & & & & & $\begin{array}{l}0.420^{*} \\
(0.171)\end{array}$ & & \\
\hline Log of Pillar6 score (Skills) & & & & & & $\begin{array}{c}0.558 * * * \\
(0.087)\end{array}$ & \\
\hline Log of Pillar7 score (Product market) & & & & & & & $\begin{array}{c}0.732 * * * \\
(0.111)\end{array}$ \\
\hline Log of Pillar8 score (Labour market) & & & & & & & \\
\hline Log of Pillar9 score (Financial system) & & & & & & & \\
\hline Log of Pillar10 score (Market size) & & & & & & & \\
\hline $\begin{array}{l}\text { Log of Pillar11 score } \quad \text { (Business } \\
\text { dynamism) }\end{array}$ & & & & & & & \\
\hline $\begin{array}{l}\text { Log of Pillar12 score (Innovation } \\
\text { capability) }\end{array}$ & & & & & & & \\
\hline
\end{tabular}




\begin{tabular}{|c|c|c|c|c|c|c|c|}
\hline Dummy variable 2 (Azerbaijan) ${ }^{1}$ & $\begin{array}{l}0.236 * * * \\
(0.030)\end{array}$ & $\begin{array}{l}0.229 * * * \\
(0.029)\end{array}$ & $\begin{array}{l}0.218 * * * \\
(0.020)\end{array}$ & $\begin{array}{c}0.197 * * * \\
(0.036)\end{array}$ & $\begin{array}{c}0.303 * * * \\
(0.029)\end{array}$ & $\begin{array}{c}0.278 * * * \\
(0.031)\end{array}$ & $\begin{array}{c}0.252 * * * \\
(0.027)\end{array}$ \\
\hline \multirow{2}{*}{ Dummy variable 3 (Georgia) } & 0.009 & 0.021 & 0.041 & 0.070 & 0.045 & $0.081 *$ & 0.029 \\
\hline & $(0.042)$ & $(0.040)$ & $(0.026)$ & $(0.036)$ & $(0.053)$ & $(0.036)$ & $(0.041)$ \\
\hline \multirow{2}{*}{ Dummy variable 4 (Kazakhstan) } & $0.734 * * *$ & $0.723 * * *$ & $0.687 * * *$ & $0.682 * * *$ & $0.757^{* * *}$ & $0.709 * * *$ & $0.741 * * *$ \\
\hline & $(0.026)$ & $(0.026)$ & $(0.020)$ & $(0.042)$ & $(0.038)$ & $(0.028)$ & $(0.026)$ \\
\hline \multirow{2}{*}{ Dummy variable 5 (Moldova) } & -0.010 & -0.064 & $-0.155^{* * *}$ & -0.092 & -0.080 & $-0.073^{*}$ & -0.043 \\
\hline & $(0.05)$ & $(0.032)$ & $(0.025)$ & $(0.047)$ & $(0.052)$ & $(0.036)$ & $(0.039)$ \\
\hline \multirow{2}{*}{ Dummy variable 6 (Russia) } & $0.945^{* * *}$ & $0.788 * * *$ & $0.793 * * *$ & $0.807^{* * *}$ & $0.856 * * *$ & $0.774 * * *$ & $0.943 * * *$ \\
\hline & $(0.030)$ & $(0.028)$ & $(0.024)$ & $(0.032)$ & $(0.033)$ & $(0.024)$ & $(0.026)$ \\
\hline \multirow{2}{*}{ Dummy variable 7 (Ukraine) } & $-0.144 * *$ & $-0.299 * * *$ & $-0.272 * * *$ & $-0.189 * * *$ & $-0.291 * * *$ & $-0.377 * * *$ & $-0.197 * * *$ \\
\hline & $(0.043)$ & $(0.035)$ & $(0.028)$ & $(0.033)$ & $(0.035)$ & $(0.032)$ & $(0.034)$ \\
\hline \multirow{2}{*}{ Intercept } & $7.397 * * *$ & $7.947 * * *$ & $7.708 * * *$ & $7.782 * * *$ & $7.456^{* * *}$ & $7.057 * * *$ & $6.355^{* * *}$ \\
\hline & $(0.382)$ & $(0.201)$ & $(0.157)$ & $(0.287)$ & $(0.734)$ & $(0.349)$ & $(0.446)$ \\
\hline Number of observations & 83 & 83 & 83 & 83 & 83 & 83 & 83 \\
\hline R-squared & 0.958 & 0.967 & 0.982 & 0.960 & 0.946 & 0.966 & 0.963 \\
\hline Adjusted R-squared & 0.955 & 0.964 & 0.980 & 0.957 & 0.941 & 0.963 & 0.960 \\
\hline \multirow[t]{2}{*}{ F-test (model) } & $443.78 * * *$ & $475.12 * * *$ & $630.58 * * *$ & $465.81 * * *$ & $379^{* * *}$ & $570.52 * * *$ & $458.26^{* * *}$ \\
\hline & (8) & (9) & (10) & (11) & (12) & (13) & (14) \\
\hline Variable & \multicolumn{7}{|c|}{ Log of GDP per capita } \\
\hline \multirow[t]{2}{*}{ Log of GCI 4.0 score } & & & & & & & $1.776^{* * *}$ \\
\hline & & & & & & & $(0.199)$ \\
\hline \multirow[t]{2}{*}{ Log of Pillar1 score (Institutions) } & & & & & & -0.009 & \\
\hline & & & & & & $(0.145)$ & \\
\hline \multirow{2}{*}{ Log of Pillar2 score (Infrastructure) } & & & & & & -0.057 & \\
\hline & & & & & & $(0.079)$ & \\
\hline \multirow{2}{*}{ Log of Pillar3 score (ICT adoption) } & & & & & & $0.279 * *$ & \\
\hline & & & & & & $(0.084)$ & \\
\hline \multirow{2}{*}{$\begin{array}{l}\text { Log of Pillar4 score (Macroeconomic } \\
\text { stability) }\end{array}$} & & & & & & $0.192 * * *$ & \\
\hline & & & & & & $(0.054)$ & \\
\hline \multirow{2}{*}{ Log of Pillar5 score (Health) } & & & & & & $0.365^{* * *}$ & \\
\hline & & & & & & $(0.130)$ & \\
\hline \multirow[t]{2}{*}{ Log of Pillar6 score (Skills) } & & & & & & -0.207 & \\
\hline & & & & & & $(0.154)$ & \\
\hline \multirow[t]{2}{*}{ Log of Pillar7 score (Product market) } & & & & & & 0.058 & \\
\hline & & & & & & $(0.159)$ & \\
\hline \multirow{2}{*}{ Log of Pillar8 score (Labour market) } & -0.066 & & & & & -0.161 & \\
\hline & $(0.250)$ & & & & & $(0.175)$ & \\
\hline \multirow{2}{*}{ Log of Pillar9 score (Financial system) } & & $0.257 *$ & & & & -0.046 & \\
\hline & & $(0.101)$ & & & & $(0.109)$ & \\
\hline \multirow{2}{*}{ Log of Pillar10 score (Market size) } & & & $0.611^{* *}$ & & & $0.256^{* *}$ & \\
\hline & & & $(0.188)$ & & & $(0.122)$ & \\
\hline
\end{tabular}




\begin{tabular}{|c|c|c|c|c|c|c|c|}
\hline $\begin{array}{l}\text { Log of Pillar11 score } \quad \text { (Business } \\
\text { dynamism) }\end{array}$ & & & & $\begin{array}{c}0.412 * * * \\
(0.058)\end{array}$ & & $\begin{array}{c}0.175 \\
(0.154)\end{array}$ & \\
\hline $\begin{array}{l}\text { Log of Pillar12 score (Innovation } \\
\text { capability) }\end{array}$ & & & & & $\begin{array}{c}0.481 * * * \\
(0.102)\end{array}$ & $\begin{array}{l}-0.043 \\
(0.104)\end{array}$ & \\
\hline Dummy variable 2 (Azerbaijan) ${ }^{1}$ & $\begin{array}{c}0.284 * * * \\
(0.045)\end{array}$ & $\begin{array}{c}0.280^{* * *} \\
(0.035)\end{array}$ & $\begin{array}{c}0.009 \\
(0.085)\end{array}$ & $\begin{array}{l}0.226^{* * *} \\
(0.028)\end{array}$ & $\begin{array}{l}0.185^{* * *} \\
(0.0334)\end{array}$ & $\begin{array}{l}0.107 * * \\
(0.045)\end{array}$ & $\begin{array}{c}0.011 \\
(0.075)\end{array}$ \\
\hline Dummy variable 3 (Georgia) & $\begin{array}{c}0.062 \\
(0.056)\end{array}$ & $\begin{array}{c}0.051 \\
(0.050)\end{array}$ & $\begin{array}{l}-0.022 \\
(0.041)\end{array}$ & $\begin{array}{l}0.077^{*} \\
(0.037)\end{array}$ & $\begin{array}{l}0.128^{* *} \\
(0.043)\end{array}$ & $\begin{array}{c}0.011 \\
(0.042)\end{array}$ & $\begin{array}{c}0.003 \\
(0.040)\end{array}$ \\
\hline Dummy variable 4 (Kazakhstan) & $\begin{array}{l}0.759 * * * \\
(0.050)\end{array}$ & $\begin{array}{l}0.771^{* * *} \\
(0.037)\end{array}$ & $\begin{array}{l}0.385^{* *} \\
(0.145)\end{array}$ & $\begin{array}{l}0.741^{* * *} \\
(0.029)\end{array}$ & $\begin{array}{c}0.749 * * * \\
(0.034)\end{array}$ & $\begin{array}{l}0.546^{* * *} \\
(0.064)\end{array}$ & $\begin{array}{l}0.57 * * * \\
(0.047)\end{array}$ \\
\hline Dummy variable 5 (Moldova) & $\begin{array}{l}-0.095 \\
(0.063)\end{array}$ & $\begin{array}{l}-0.056 \\
(0.057)\end{array}$ & $\begin{array}{l}-0.043 \\
(0.028)\end{array}$ & $\begin{array}{l}-0.046 \\
(0.035)\end{array}$ & $\begin{array}{c}0.028 \\
(0.059)\end{array}$ & $\begin{array}{c}-0.129 * * * \\
(0.038)\end{array}$ & $\begin{array}{l}-0.047 \\
(0.044)\end{array}$ \\
\hline Dummy variable 6 (Russia) & $\begin{array}{c}0.872 * * * \\
(0.032)\end{array}$ & $\begin{array}{c}0.909 * * * \\
(0.031)\end{array}$ & $\begin{array}{c}0.253 \\
(0.191)\end{array}$ & $\begin{array}{c}0.867 * * * \\
(0.023)\end{array}$ & $\begin{array}{c}0.783 * * * \\
(0.030)\end{array}$ & $\begin{array}{c}0.557 * * * \\
(0.104)\end{array}$ & $\begin{array}{c}0.686^{* * * *} \\
(0.046)\end{array}$ \\
\hline Dummy variable 7 (Ukraine) & $\begin{array}{c}-0.275^{* * *} \\
(0.033)\end{array}$ & $\begin{array}{c}-0.232^{* * *} \\
(0.032)\end{array}$ & $\begin{array}{c}-0.710^{* * *} \\
(0.135)\end{array}$ & $\begin{array}{c}-0.275^{* * *} \\
(0.024)\end{array}$ & $\begin{array}{c}-0.336^{* * *} \\
(0.028)\end{array}$ & $\begin{array}{c}-0.393 * * * \\
(0.078)\end{array}$ & $\begin{array}{c}-0.267^{* * *} \\
(0.041)\end{array}$ \\
\hline Intercept & $\begin{array}{c}9.539 * * * \\
(1.011)\end{array}$ & $\begin{array}{c}8.275 * * * \\
(0.388)\end{array}$ & $\begin{array}{c}7.209 * * * \\
(0.634)\end{array}$ & $\begin{array}{c}7.695 * * * \\
(0.224)\end{array}$ & $\begin{array}{c}7.588 * * * \\
(0.357)\end{array}$ & $\begin{array}{c}6.154 * * * \\
(0.872)\end{array}$ & $\begin{array}{l}2.25^{* *} \\
(0.784)\end{array}$ \\
\hline Number of observations & 83 & 83 & 83 & 83 & 83 & 83 & 104 \\
\hline R-squared & 0.942 & 0.947 & 0.969 & 0.965 & 0.955 & 0.989 & 0.926 \\
\hline Adjusted R-squared & 0.937 & 0.942 & 0.966 & 0.961 & 0.951 & 0.985 & 0.92 \\
\hline F-test (model) & $567.52 * * *$ & $774.24 * * *$ & $990.54 * * *$ & $464.97 * * *$ & $372.41 * * *$ & $305.12 * * *$ & $224.96 * * *$ \\
\hline
\end{tabular}

$* \mathrm{p}<0.1 ; * * \mathrm{p}<0.05 ; * * * \mathrm{p}<0.01$

${ }^{1}$ Dummy variable 1 (Armenia)

\subsubsection{Individual Factors Effects}

To look at the individual effects of the factors of competitiveness (the GCI pillars scores) on per capita income, the $\log$ value of the factors is separately regressed on the dependent variable - log of the GDP per capita and the estimated results are tabulated in the columns from 1 till 12 (Table 4). As the results exhibit, almost all factors (except labour market) have an influence on per capita income in the selected post-Soviet countries between 2007 and 2018 and it is statistically significant. Dummy variable parameters of Georgia and Moldova are found as statistically insignificant for majority of factors, whereas those of other countries are statistically significant for almost all factors. Furthermore, F-test achieves a significance level of $99 \%$ and R-squared/adjusted R-squared is greater than 0.90 in all of these simple regression equations.

The statistically significant coefficients with positive signs conform with the GCI theoretical framework, which argues that the GCI pillars, seen as levers of productivity growth, have positive impact upon per capita income. The main reason for statistically insignificant coefficient of the labour market pillar is associated with a relatively weak performance of the countries in this pillar. According to Figure 3, almost all countries' scores demonstrated an upward trend in the last two years after a steady decline from 2005 and 2017. In contrast with 2005, the scores (except Armenia) are remained almost unchanged in 2019. As the GCI methodology suggests, it is caused by unfavourable labour market conditions, such as high redundancy costs, complicated hiring and firing practices, weak cooperation in labour-employer relations, lack of flexibility of wage determination and active labour market policies, and limited internal labour mobility. 


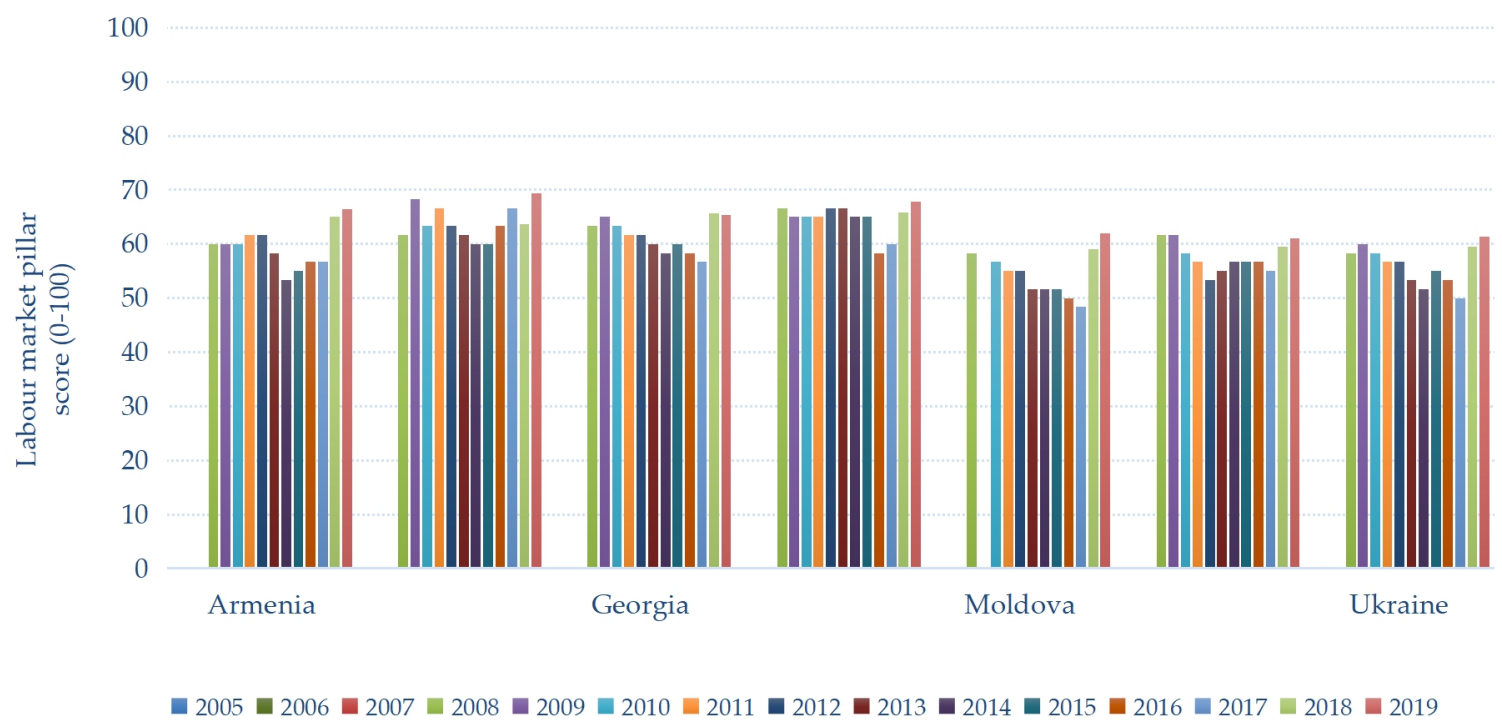

Figure 3. Competitiveness and income

\subsubsection{Multiple Factors Effects}

Finally, the predicted multiple regression results (Column 13) show that 4 out of 12 factors, including "ICT adoption", "Macroeconomic stability", "Health" and "Market size" have positive signs that are statistically significant. R-squared is 0.989 , meaning that 98.9 percent of variations in the per capita income in the selected post-Soviet countries from 2007 to 2018 can be explained by these 4 factors. Besides Georgia, the dummy variable coefficients of all other countries have a statistical significance. The greatest coefficients belong to Russia (0.557) and Kazakhstan (0.546), while the smallest ones to Ukraine (-0.393) and Moldova (-0.129). In turn, this implies that among the reviewed former Soviet countries, Russia and Kazakhstan are the most successful countries maintaining relatively higher national competitiveness that resulted in higher per capita income in the long-term.

\subsubsection{ICT Advancement and Income Level}

Now, turning to the details, one of the key indicators of the ICT adoption pillar is a number of Internet users. In fact, between 2005 and 2017, a percentage of individuals using the Internet climbed from 5.25\% to $64.74 \%$ in Armenia, from $8.03 \% 79 \%$ in Azerbaijan, from $6.08 \%$ to $59.71 \%$ in Georgia, from $2.96 \%$ to $76.43 \%$ in Kazakhstan, from $14.63 \%$ to $76.12 \%$ in Moldova, from $15.23 \%$ to $76.01 \%$ in Russia and from $3.75 \%$ to $58.89 \%$ in Ukraine. Meanwhile, fixed-broadband subscriptions per 100 inhabitants augmented by 19 times in Russia, more than 40 times in Ukraine and Moldova, and more than 100 times in Armenia, Azerbaijan, Georgia and Kazakhstan (International Telecommunication Union, 2020). These are great figures and herein, it is worth noticing that the development of ICTs substantially accelerated information exchange and knowledge sharing, stimulated innovations, decreased transaction costs and improved efficiency in these countries. Moreover, given the fact that ICT advancement supports the emergence of new business models leading to structural changes in the economy, it positively affected on productivity and per capita income growth in Armenia, Azerbaijan, Kazakhstan, Moldova, Russia and Ukraine over the period.

\subsubsection{Macroeconomic Stability and Income Level}

In terms of macroeconomic stability, the GCI focuses on the level of inflation and the sustainability of fiscal policy. As can be seen in Figure 4, the greatest average annual inflation rate between 2004 and 2018 is registered in Ukraine $(13.56 \%)$. In all other countries, the average annual rate of inflation throughout the period was less than $10 \%$ (World Bank, 2020). Despite Global Financial crisis in 2008 and dramatic downfalls in prices for natural resources (i.e. oil and gas), the inflation targeting policies of these countries enabled to decrease the inflation rate to moderate levels (2.26\% in Azerbaijan, 2.52\% in Armenia, 2.62\% in Georgia, 2.88\% in Russia, 3.05\% in Moldova and 6.02\% in Kazakhstan) in 2018 and made it more predictable. Yet, Ukraine is an exceptional case because political instability and social unrest destabilized the economy of the country. As a result, the annual inflation rate rocketed to $48.7 \%$ in 
2015 and afterwards, began to steadily fall (World Bank, 2020). In general, relatively moderate and predictable level of inflation rate and public debt provided these countries with macroeconomic stability, which allowed business and investors to be certain about expected returns on their investments. On the one hand, it uplifted the FDI inflow and productivity growth. On the other hand, increased business confidence prevented the capital outflow and its economic consequences.

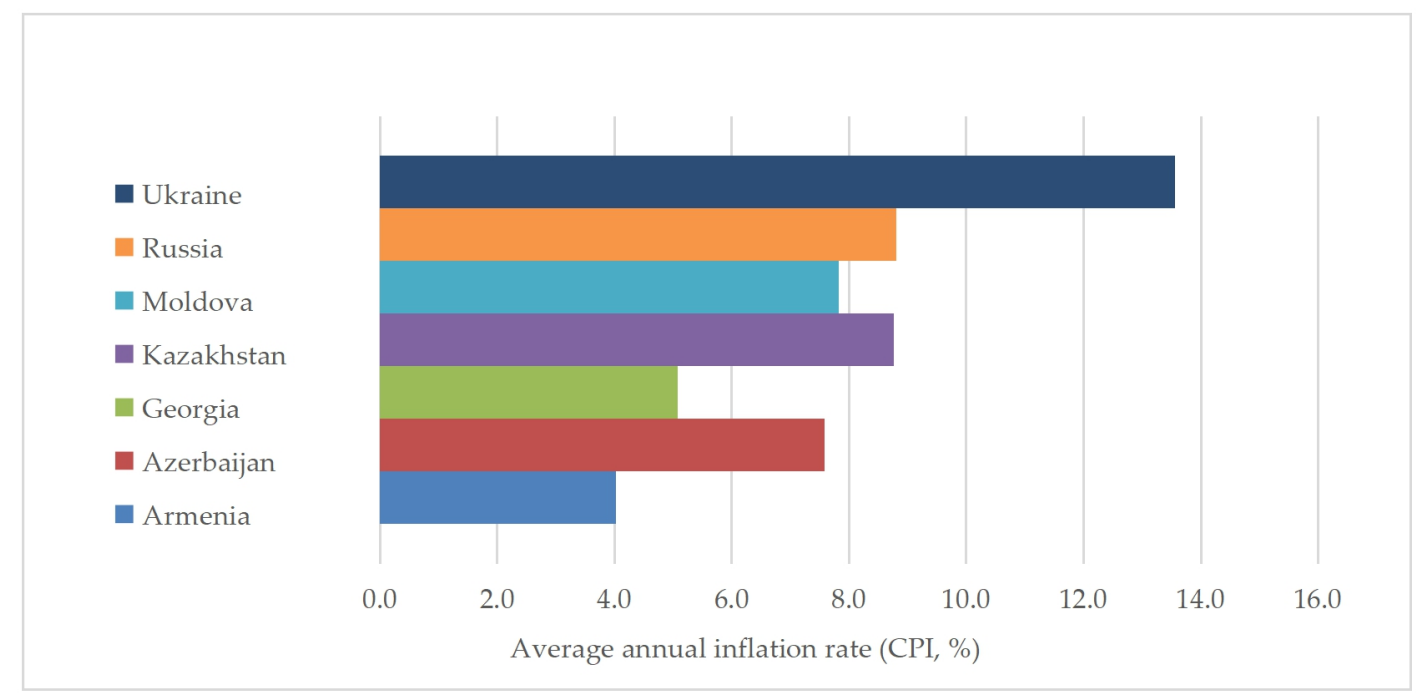

Figure 4. Average annual inflation rate (CPI), 2004-2018

\subsubsection{Market Size and Income Level}

The next factor, which had a positive impact on per capita income growth in the selected former Soviet states between 2004 and 2018 is a market size. By market size, the GCI means GDP (PPP) and import volume of goods and services. These economic indicators denote the size of the domestic market for domestic and foreign producers, respectively and overall openness of the country toward international trade as whole. According to the World Development Indicators of the World Bank, the GDP of Armenia, Georgia and Kazakhstan roughly doubled in the period of 2004-2018 years, whereas that of Azerbaijan tripled. Meanwhile, in Russia and Moldova, the GDP incremented by 1.44 and 1.72 times, respectively. In contrast, the import (constant 2010) from abroad rose by 2 and more than 2 times in Georgia, Russia, Moldova and Azerbaijan at that period. Relatively lower growth is registered in Armenia (1.55 times) and Kazakhstan (1.71 times). In case of Ukraine, the growth in both indicators is very negligible. These figures indicate that the observed countries became more open to international trade as their markets expanded. Schwab (2018), Idris, et al. (2018) and Tan et al. (2018) also suggest that large market size creates economies of scale for business reducing unit cost of production and thus, leaping their productivity growth. Besides, such markets facilitate human capital accumulation and knowledge exchange that raise returns on innovations (Palaniaandy and Chin, 2018).

\subsubsection{Healthy Life Expectancy and Income Level}

Figure 5 summarizes a life expectancy at birth data in the selected post-Soviet countries between 2004 and 2018. As the graph illustrates, the indicators of all countries significantly grew over the period. The largest increase was observed in Kazakhstan (by 7.3 years) and Russia (by 7.2 years), followed by Azerbaijan (by 4.6 years), Moldova (by 4.1 years), Ukraine (by 3.4 years), Georgia (by 3.1 years) and Armenia (by 2.4 years). In general, the healthy life expectancy is an important input of the human capital as healthier people tend to have more powerful physical and mental abilities, being more productive and innovative, and increasing life expectancy encourages the individuals to invest more in their skillset and education Thereby improvements in human capital positively contributed to the growth of productivity and income level in these countries. 


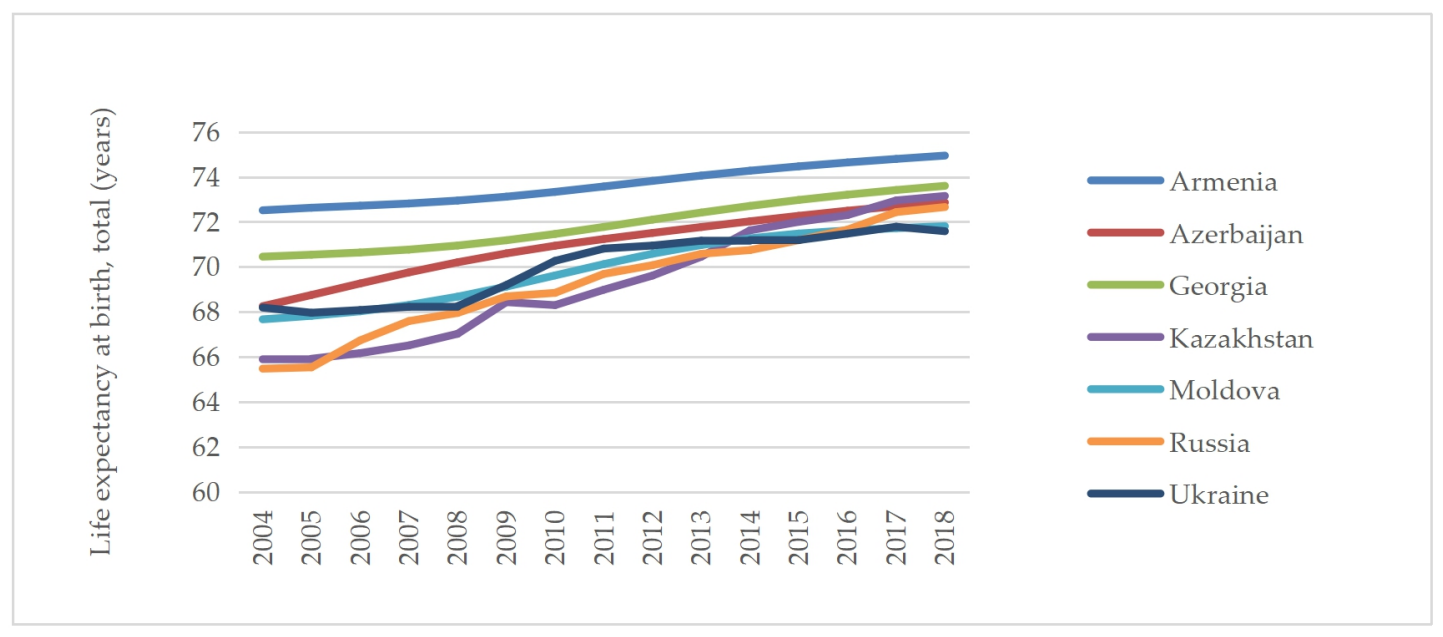

Figure 5. Life expectancy at birth

\section{Conclusions}

This paper aims to test whether a productivity growth and an increase in income per capita is associated with higher national competitiveness in the selected former-Soviet countries between 2004 and 2018. The latest version of the Global Competitiveness Index (GCI 2019), which is composed of 12 pillars such as institutions, infrastructure, ICT adoption, macroeconomic stability, health, skills, product market, labour market, financial system, market size, business dynamism and innovation capability is used as a proxy for the national competitiveness and productivity for the empirical analysis purposes. The first objective of the following study is to examine whether enhancement of the national competitiveness of the selected post-Soviet countries led to higher productivity and growth between 2000 and 2018. The empirical results suggest that the GCI is highly correlated with productivity level and the selected post-Soviet countries with higher level of national competitiveness had higher long-term economic growth and income per capita.

The second objective of this study is to estimate the country-specific effects of the national competitiveness factors upon the per capita income over time. The obtained results suggest that these effects are mediated by the difference across countries. Looking at the individual effects of the GCI factors, almost all factors (except labour market) had an influence on per capita income in the selected former Soviet countries between 2007 and 2018. However, the multiple factors effects show among the GCI factors, ICT adoption, macroeconomic stability, market size and healthy life expectancy were major levers of productivity growth that influenced the national competitiveness, positively and significantly contributing to an increase in the income level in the selected post-Soviet countries in 2004-2018 period.

These findings indicate that the development of ICTs, the stability of macroeconomic, the size of GDP and the health of human capital are vital for a nation's productivity and income growth. In addition, the study also found that higher per capita income in Armenia, Kazakhstan, Russia and Ukraine is associated with the improved national competitiveness. Yet, Russia and Kazakhstan more benefited from rising per capita income associated with enhanced national competitiveness (or productivity growth) in comparison with others.

The policy implications from this study are straightforward. Firstly, ICTs development has a vital importance for the growth of productivity and income, since it accelerates information exchange and knowledge sharing, stimulates innovations, and decreases transaction costs. Therefore, it shall be the top priority of the development agenda in the selected post-Soviet countries.

Secondly, the governments should maintain a macroeconomic stability, low and predictable inflation, sustainable fiscal policy, FDI friendly environment to promote business confidence, encourage FDI inflow, and increase technology transfer that will lead to the growth of productivity and income level in the long run.

Thirdly, the countries shall be more open to international trade to expand their markets for domestic as well as foreign manufacturers. In fact, the large market size creates the economies of scale, reduces average cost of production and thus improves productivity and income growth. The economic cooperation of these countries 
shouldn't limited at the current stage of CIS free trade area, but also they shall work towards higher level of economic integration.

Fourthly, policy makers need to be aware that labour is an important input for economic growth. The government shall ensure the provision of public health and infrastructure is sufficient, provide more opportunity of training and education to facilitate human capital accumulation. Healthier people tend to have more powerful physical and mental abilities, being more innovative and productive.

Finally, the following study reveals that the coefficients of two-thirds of the GCI factors for the selected post-Soviet countries are statistically insignificant and/or have opposite sign which contradicts the underlying theory. These are institutions, infrastructure, skills, product market, labour market, financial system, business dynamism and innovation capability pillars. In general, this finding implies that the selected former Soviet states are still underperforming their potentials to enhance the national competitiveness as they are failed in developing institutions, product, labour and financial markets, improving general infrastructure, education system and innovation potential, and providing favourable business climate. Indeed, these competitiveness factors are rooms to improve for such countries.

\section{Acknowledgement}

This research was funded by Ministry of Finance of the Republic of Uzbekistan, grant number MY-Ф3-201909052 through Creation of the "Republic of Uzbekistan in the international rankings" web-portal and development of long-term strategy for working with international ratings and indices. This paper represents the personal opinions of individual staff members and is not meant to represent the position or opinions of the Ministry of Finance or its Members, nor the official position of any staff members or even those of the staff of the University Putra Malaysia. The authors would like to express their sincere gratitude to Odilbek Isakov, Deputy Finance Minister and Temur Malik Narzikulov, Head of Department, International Ratings and Indices Department, Ministry of Finance, 100017, 29, Istiklol St., Tashkent city, Uzbekistan for his support and encouragement.

\section{References}

Alexoaei, A. P. (2020). The relevance of national competitiveness for the entrepreneurial environment. The Romanian Economic Journal, 23(77), 64-76.

Barro, R. J., \& Sala-i-Martin, X. (1992). Convergence. Journal of Political Economy, 100(2), 223-251.

Barro, R. J., \& Sala-i-Martin, X. (2004). Economic Growth (2nd ed.). Cambridge: The MIT Press.

BBC. (2014). Ukraine crisis: Timeline. Retrieved 27th July 2020, from https://www.bbc.com/news/world-middle-east-26248275

Berger, T., \& Bristow, G. (2009). Competitiveness and the Benchmarking of Nations - A Critical Reflection. International Advances in Economic Research, 15(4), 378-392.

Berger, T. (2008). Concepts of national competitiveness. Journal of International Business and Economy, 9(1), 91-111.

Bristow, G. (2005). Everyone's a "winner": Problematising the discourse of regional competitiveness. Journal of Economic Geography, 5(3), 285-304. https://doi.org/10.1093/jeg/lbh063

Buckley, P. J., Pass, C. L., \& Prescott, K. (1998). Measures of International Competitiveness: A critical survey. Journal of Marketing Management, 4(2), 175-200.

Carvalho, L., Di Serio, L. C., \& Vasconcellos, M. (2012). Competitiveness of Nations: Review of the Metric Used by the World Economic Forum. Revista de Administração de Empresas, 52(4), 421-434.

Cornelius, P. (2002). Creating Value: From Comparative to Competitive Advantage. Some Conceptual Issues. Executive Forum on National Export Strategies.

Dadgar, Y., Nazari, R., \& Fahimifar, F. (2018). The Impact of Global Competitiveness Index (GCI) on Economic Growth in Iran and Some Selected Countries. OIDA International Journal of Sustainable Development, 11(12), 53-60.

Engel, L. C., \& Siczek, M. M. (2018). A cross-national comparison of international strategies: global citizenship and the advancement of national competitiveness. Compare, 48(5), 749-767. https://doi.org/10.1080/03057925.2017.1353408

Guerrero, M., Urbano, D., \& Fayolle, A. (2016). Entrepreneurial activity and regional competitiveness: evidence 
from European entrepreneurial universities. The Journal of Technology Transfer, 41(1), 105-131. https://doi.org/10.1007/s10961-014-9377-4

Hall, R. E., \& Jones, C. I. (1999). Why Do Some Countries Produce So Much More Output per Worker Than Others?. The Quarterly Journal of Economics, 114(1), 83-116.

Herman, E. (2018). Innovation and entrepreneurship for competitiveness in the EU: an empirical analysis. Proceedings of the International Conference on Business Excellence, 12(1), 425-435. https://doi.org/10.2478/picbe-2018-0038

Hibbs, M. (1983). Minding America's Business: The Decline and Rise of the American Economy by Ira C. Magaziner and Robert B. Reich, and The Deindustrialization of America: Plant Closings, Community Abandonment, and the Dismantling of Basic Industry by Barry Bluestone and B. Challenge, 26(1), 62-65. https://doi.org/10.1080/05775132.1983.11470834

Hoechle, D. (no date). Robust Standard Errors for Panel Regressions with Cross-Sectional Dependence. The Stata Journal. Retrieved 20th July 2020, from http://fmwww.bc.edu/repec/bocode/x/xtscc_paper.pdf

Idris, J., Yusop, Z., Habibullah, M. S., \& Chin, L. (2018). Openness and Economic Growth in Developing and OECD Countries. International Journal of Economics and Management, 12(2), 693-702.

Im, T., \& Choi, Y. (2018). Rethinking National Competitiveness: A Critical Assessment of Governmental Capacity Measures. Social Indicators Research, 135, 515-532. https://doi.org/10.1007/s11205-016-

IMD. (2003). World Competitiveness Yearbook 2003. Lausanne: Bellerive.

International Telecommunication Union. (2020). Statistics. Retrieved 26th July 2020, from https://www.itu.int/en/ITU-D/Statistics/Pages/stat/default.aspx

Kharlamova, G., \& Vertelieva, O. (2013). The International Competitiveness of Countries: Economic-Mathematical Approach. Economics \& Sociology, 6(2), 39-52.

Kitson, M., Martin, R., \& Tyler, P. (2004). Regional competitiveness: An elusive yet key concept?. Regional Studies, 38(9), 991-999. https://doi.org/10.1080/0034340042000320816

Kordalska, A., \& Olczyk, M. (2015). Global Competitiveness and Economic Growth: A One-Way or Two-Way Relationship?. Institute of Economic Research Working Papers No. 63.

Krugman, P. (1994). Competitiveness: A Dangerous Obsession. Foreign of Affairs, 73(2), 28-44.

Mankiw, N. G., Romer, D., \& Neil, D. N. (1992). A Contribution to the Empirics of Economic Growth. NBER working paper no. 3541, National Bureau of Economic Research.

Mihaela, S. (2016). Competitiveness and Economic Growth in Romanian Regions. Journal of Competitiveness, 8(4), 46-60. https://doi.org/10.7441/joc.2016.04.03

Nguyen, H. P. (2009). National Competitiveness of Vietnam: Determinants, Emerging Key Issues and Recommendations. Switzerland: The Peter Lang Publishing Group.

OECD. (1992). Technology and the Economy: The Key Relationships. Paris: OECD.

Palaniaandy, A., \& Chin, L. (2018). Intellectual Property Rights, Foreign Direct Investment and Economic Growth, International Journal of Economics and Management, 12(S2), 535-548.

Petryle, V. (2016). Does the Global Competitiveness Index Demonstrate the Resilience of Countries to Economic Crises?. Ekonomika, 95(3), 28-36.

Porter, M. E. (1990). The Competitive Advantage of Nations. London: The Macmillan Press.

Porter, M. E. (2003). The Economic Performance of Region. Regional Studies, 37(6-7), 549-678.

Porter, M. E., Sachs, J. D., Warner, A. M., Cornelius, P. K., Levinson, M., \& Schwab, K. (2000). The Global Competitiveness Report 2000. New York: Oxford University Press.

Reyes, G. E., \& Useche, A. J. (2019). Competitiveness, economic growth and human development in Latin American and Caribbean countries 2006-2015: A performance and correlation analysis. Competitiveness Review, 29(2), 139-159. https://doi.org/10.1108/CR-11-2017-0085

Rusu, V. D., \& Roman, A. (2018). An Empirical Analysis of Factors Affecting Competitiveness of C.E.E. Countries. Economic Research-Ekonomska Istraživanja, 31(1), 2044-2059. 
Schwab, K. (2018). The Global Competitiveness Report 2018. World Economic Forum.

Scott, B. R., \& Lodge, G. C. (1985). US Competitiveness in the World Economy. Boston: Harvard Business School Press.

Solow, R. M. (1957). Technical Change and the Aggregate Production Function, Review of Economics and Statistics, 39(3), 312-320.

Sölvell, Ö. (2015). The Competitive Advantage of Nations 25 years - opening up new perspectives on competitiveness. Competitiveness Review, 25(5), 471-481. https://doi.org/10.1108/CR-07-2015-0068

Tan, J. W., Chin, L., Azali, M., \& Ismail, N. W. (2018). The Impact of Various Trade Arrangements on Malaysia's Bilateral Trade Costs. Jurnal Ekonomi Malaysia, 52(2), 69-80.

World Bank. (2020). World Development Indicators. Retrieved 15th June 2020, from: https://databank.worldbank.org/source/world-development-indicators

Zhou, Y., Zhou, W., \& Wang, J. W. (2015). New Aluminum Plated Corrugated Cardboard Material and Application. Advanced Materials Research, 1095, 535-538. https://doi.org/10.4028/www.scientific.net/amr.1095.535

\section{Copyrights}

Copyright for this article is retained by the author(s), with first publication rights granted to the journal.

This is an open-access article distributed under the terms and conditions of the Creative Commons Attribution license (http://creativecommons.org/licenses/by/4.0/). 